\title{
次世代シーケンサーを用いた新たな原因遺伝子同定法 イネ有用遺伝子領域同定への席用
}

遺伝学の研究目的の一つは, 生物種の個体間の表現型 変異の原因となっている遺伝的変異を特定することであ る。この目的のために，遺伝的連関 (genetic association）の解析が利用されてきた。すなわち，生物種の集 団を表現型によって2種類以上のグループに分類したと き，その分類と統計的に有意な連関（association）を示 すようなゲノム上の変異を探す解析である．ゲノムが親 から子孫に遺伝する際に，物理的に互いに近くにある DNA 領域は，より高い頻度で一緒に子孫に伝達される ため, 強い連関が見られる。一方，互いに離れた位置に ある2つのDNA 領域間では，領域間の組換えにより子 孫への伝達が独立になり，連関が弱くなる。したがっ て, 表現型の分類と特定のゲノムの変異の連関を観察す ることにより，表現型を決定するゲノム領域を推定する ことが可能となる．遺伝的連関解析のなかで，最も多用 される手法が連鎖解析（linkage analysis）である，連鎖 解析では, 異なる表現型を示す 2 個体を交配し, 子孫を 得る。これらの子孫の個体間で，注目している表現型が 分離するとき，表現型の分離と連関して分離するような ゲノム領域を見つける手法である。連鎖解析では，ゲノ 厶領域を可視化して標識するためにDNA マーカーが利 用されている．ゲノム上の任意の場所を選び，そこに交 配親間で異なるDNA 配列を見いだし，マーカーとして 用いる。ゲノム上を広く覆うような DNA マーカーを開 発することができれば，親から子孫への DNA マーカー の伝達を調べることによりゲノム全体の伝達の仕方を推 測することが可能である，過去の連鎖解析では，交配後 の子孫における表現型の分離と連鎖したDNA マーカー を同定し，原因遺伝子の扮扮まかな位置を見いだした 後, その近傍にさらに多数のDNA マーカーを設定して 連鎖解析を続けることにより, 原因遺伝子領域を狭めて 最終的に原因遺伝子を同定した。この作業には多くの分 離個体, 多数の DNA マーカー, 労力と時間とが必要と された。

一方，交配を伴わずに遺伝的連関解析をする手法も近 年広く利用されるようになってきた。特に全ゲノム連関 解析法 (Whole Genome Association Study; WGAS) と 呼ばれる手法は，集団に自然に存在する個体や系統を対
象に，表現型で2群に区別し，この2群と連関を示す変 異をゲノム全体から探索する手法である ${ }^{(1)}$.WGASで は，人工的な交配を用いず，生物種の進化過程で自然に 生じた組換えを利用して, 連関解析を行う。

ゲノム上の DNAの配列解読（DNA シーケンシング） には，1974年の発明以来，30年にわたり主にサンガー 法が利用されてきた。 2005 年前後に,「次世代シーケン ス」技術が利用され始めた。 454社の pyrosequencingに 続き, Solexa社のIllumina シーケンシング, ABI社の SOLiD シーケンシングなどが利用可能になった。「次世 代シーケンス」の発達により, 生物の全ゲノム配列の新 規決定 (de novo assembly と呼ぶ) が飛躍的に容易に なった．その結果，おおまかな全ゲノム配列の決定され た生物種数は指数的に増えている. de novo assembly は，多くの場合，一種の特定の1個体について実施す る.こうして得られた配列を，その生物種の基準配列 (reference sequence) と呼ぶ. 同種に属する別の個体 からゲノム配列を解読して基準配列と比較する作業を, リシーケンシング (re-sequencing) と呼ぶ. リシーケン シングが飛躍的に容易になれば, DNA マーカーが不必 要になることは自明である。ゲノムから抽出した標本 (DNA マーカー) の解析が，母集団（ゲノム全体）の解 析によって置き換えられる時代が到来した。

リシーケンシングにより，生物の全ゲノム配列を解析 することにより, 表現型の変異と遺伝子変異の連関を解 析することが可能になった．前述したWGASは，すで に多くの生物で適用されている. 交配後の分離集団にお いて，リシーケンシングにより原因遺伝子を同定する技 術も開発されてきた。これには, SHOREmap ${ }^{(2)}, \mathrm{X}-\mathrm{QTL}$ 法 $^{(3)}$, MutMap 法 ${ }^{(4)}$, QTL-seq 法(5) などがある. 以下, 筆者らが開発したMutMap 法と, QTL-seq 法について 紹介する。

筆者らの所属する岩手生物工学研究センターでは, 岩 手県農業研究センターと共同で, 岩手県に適した優良水 稲品種の育種を進めている。その目的のために，東北の 水稲主力品種「ひとめほれ」を材料に, EMS処理によ り作出した15,000系統の突然変異系統群と,「ひとめぼ れ」と世界の 20 種類以上のイネを交配して得られた約 


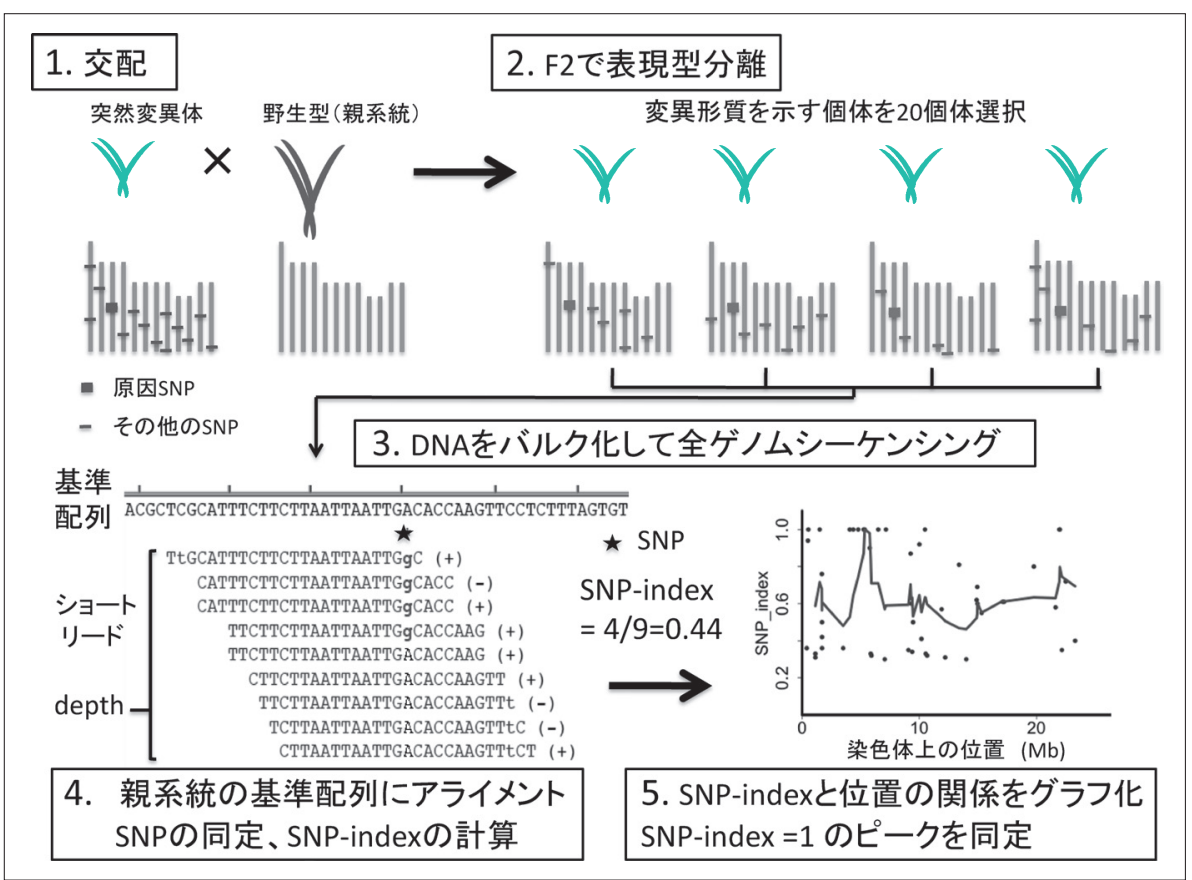

\section{図 1・MutMap法の概略}

（1）表現型に興味をもった突然変異 体（劣性）を親系統に交配する。イ ネを例に 12 本の染色体のゲノムの様 子を示している。（2）F2世代で変異 形質をもつ子孫と野生型の形質を示 す個体が分離する。变異形質を示す 子孫に注目すると, これらの個体は, 原因のSNPをホモ接合で保有してい る。表現型と無関倸な SNPは, F2 個 体に，1:1の割合で遺伝する。(3) 変 異形質を示すF2個体のDNAをバル ク化し, 次世代シーケンサーで全ゲ ノムシーケンスする。 (4) 得られた ショートリードを親型の基準配列に 対してアライメントする. 各SNPに ついて, SNP-indexを計算する。 (5) 横軸に染色体上の位置, 縦軸に SNPindexをとったグラフを作成し， SNP-index =1を示すピークを探す. SNP-index $=1$ のNPのいずれかが 原因の変異である。
3,000系統の Recombinant Inbred Lines（RILs）系統群 を育成して維持している。これらの材料を利用して育種 上有用な遺伝子領域を同定し, DNA マーカー選抜法に より迅速に品種を育成することが課題である。そこで, 突然変異系統の表現型の原因遺伝子を全ゲノム解析によ り迅速に同定する技術として, MutMap 法 ${ }^{(4)}$ を開発し た（図1). 本法では，目的の表現型を示す突然変異体 と変異処理に用いた親系統（「ひとめぼれ」）とを交配す る，得られた F1個体を自家交配して，F2個体を 100 個 体程度得る。変異形質が劣性突然変異によってもたらさ れる場合, F2では，表現型が，野生型と変異型に $3: 1$ の割合で分離する．F2個体のうち，変異型を示す個体 約 20 個体のゲノムDNAを均等に混合（バルク化）し， 次世代シーケンサーにより全ゲノムシーケンスする．次 世代シーケンサーでは, 75 ～ 100 塩基の短い塩基配列 (ショートリード) が多数得られる. 得られたショート リードを, 品種「ひとめぼれ」についてあらかじめ作成 した基準配列に対してアライメントする．ゲノムの特定 箇所を何個のショートリードが覆っているかをデプス (depth) と呼ぶ. 図1の例では，デプスが9になってい る.ここで, SNP-indexという值を定義する. SNP-indexは，アライメントされたショートリードと基準配列 の間にSNPがある場合, そのSNP箇所を覆うショート リード全体のうち, 基準配列と異なる塩基をもつショー
トリードの割合である．たとえば，図 1 では，デプス 9 のうち，4リードが基準配列と異なる塩基を保有してい るので, SNP-index $=4 / 9=0.44$ となる. 突然変異形質 を示す F2 個体では，原因 SNPは，木モ接合になってい る。したがって, 変異型F2のバルク DNAでは, すべて のショートリードが変異型SNPを含んでいるはずであ る.すなわち, 原因SNPは, SNP-indexが1を示すこと が期待される，一方，表現型と関係ないSNPでは，変 異型F2のバルクDNAで, 変異型 SNPを含むショート リードと親型（野生型）ショートリードが $1: 1$ になるこ とが期待され，SNP-indexは 0.5 の期待值をもつ.また, 染色体上で原因 SNPの近くにあるSNPは，連鎖により， 0.5 と 1 の間のSNP-indexを示すことが予想される. そ こで, 突然変異体と親系統の間に存在するすべての SNP（私たちの変異系統群では平均約 2,000 個）につい てSNP-indexを計算する。次に, 横軸にSNPの染色体 上の位置, 縦軸にSNP-indexの值を示したグラフを作成 する。このグラフのなかで, SNP-indexが1となるょう なピークを探すことにより，原因 SNPを同定すること が可能である. MutMap 法は, 突然変異体を変異処理 に用いた親系統に交配してF2での分離を調べるため, 効果の小さい量的な変異の原因遺伝子同定にも効率的に 利用することができる.

育種には, 自然に存在する遺伝的変異を利用すること 


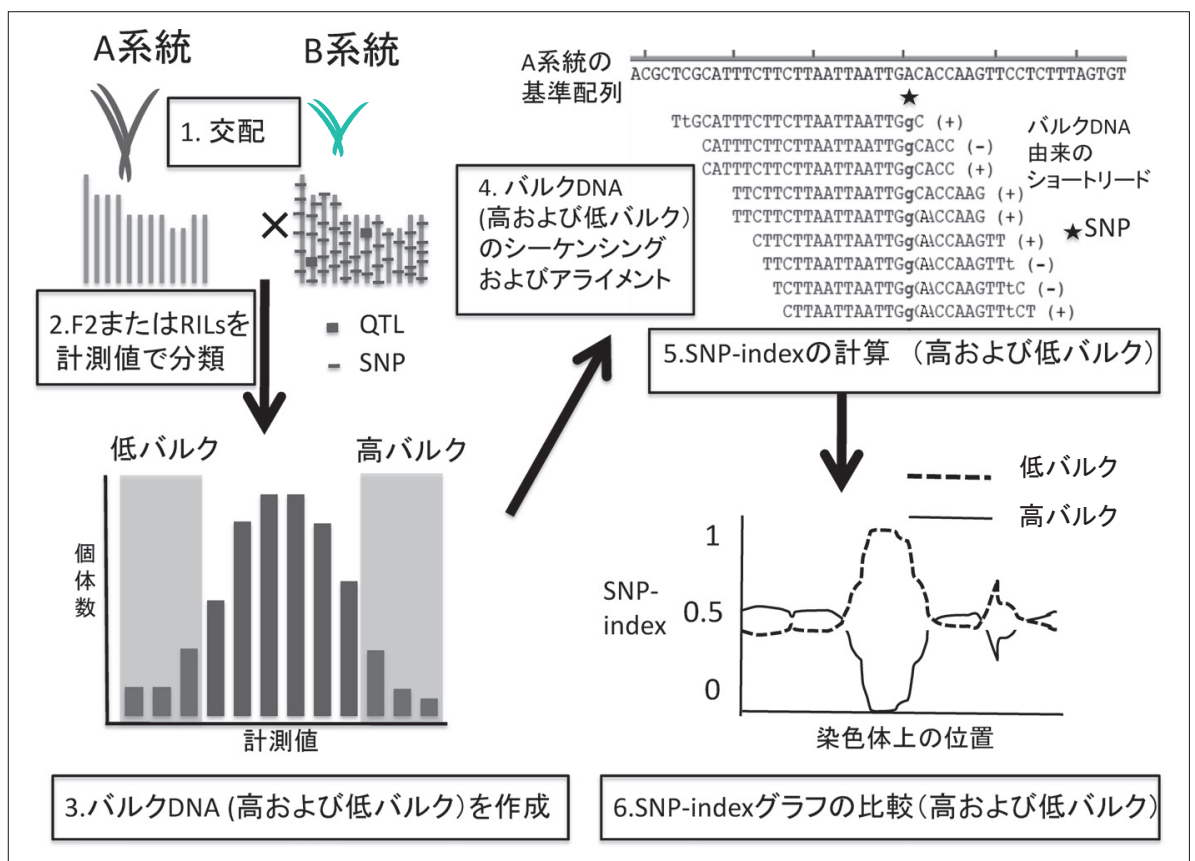

\section{図 2『QTL-seq 法の概略}

(1) 表現型が異なる2つの系統 (A系 統を B系統）を交配する。これらの系 統は, 多くのDNA変異によって異 なっている。（2）F2またはRILsを育 成し, 目的の形質を計測する. 複数 のQTLによって表現型が決定されて いる場合は，表現型の分離は，正規 分布を示す。（3）表現型の分布を観察 して，計測值が高い個体（系統）を $20 ５ 0 ，$ 低い個体（系統）を20～50 集めてそれぞれバルク化（高バルク 打よび低バルク）する。（4）2つのバ ルク DNAを A系統の基準配列にアラ イメントする. (5) 2つのバルク DNA 別々に, 各SNPについてSNP-index を計算する. (6) 2つのバルク DNA 別々に, 横軸に染色体上の位置, 縦 軸にSNP-indexをとったグラフを作 成し, 高バルクと低バルクで対照的 なパターンを示すゲノム領域を同定 する。 そうした領域に表現型の差を 支配するQTLが座乗している。
も重要である．異なる系統間で表現型に量的な差がある ときに，この差を決定している量的遺伝子座 (Quantitative Trait Loci; QTL) を同定することが求められる. 私たちは，こうした目的のためにQTL-seq 法 ${ }^{(5)}$ を開発 した（図2），QTL-seq法では，異なる形質を示す系統 間で交配を行い，F2世代を得る，F2世代の各個体を独 立の系統とみなして自家交配を続けることにより，組換 え近交系RILsを育成することも多い，F2世代もしくは RILsを栽培し, 目的の表現型を調べる。量的形質は, 複数の遺伝子座の効果が相加的に働いて決定されている ことが多い。したがって，F2やRILsでは，表現型の計 測值を横軸に, 各計測值クラスの個体数を縦軸にとって グラフを描くと，正規分布を示すような分布が得られ る.そこで，分布の両極端を示すような個体（系統） を，それぞれ $10 〜 20$ 選んで，高い值を示す個体のバル ク（高バルク）, 低い值を示す個体のバルク（低バルク） の 2 種類の個体群からバルクDNAを作成し，それぞれ 次世代シーケンサーで全ゲノム解析する。 各バルク DNAについて，得られたショートリードを，交配に用 いた親のいずれかについて作成した基準配列に対してア ライメントする，その後，両親間で存在するSNPすべ てについて，上記SNP-indexを計算する。ささらに, SNP-index と染色体の位置をグラフ化する. ゲノムの大 部分の領域では，交配親のゲノムが同じ比率で子孫に伝

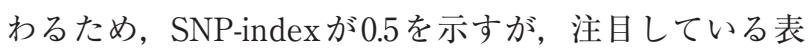
現型に寄与する遺伝子を含む領域では, SNP-indexが1 または0の方向に歪む. さらに, 高バルクと低バルク で, SNP-indexの0.5からのゆがみが正反対になるよう な場所を探す。このような場所には，目的形質を支配す るQTLが存在することが推測される.

MutMap 法, QTL-seq法ともに, 1〜2回の全ゲノム シーケンスにより原因遺伝子やQTLを同定することが 可能であり, DNA マーカーを用いた連鎖解析と比較し てはるかに短時間で作業が終わる。概念的には, MutMap 法, QTL-seq法は，交配集団に人為選択が㗢いた ときに, 遺伝的変異が減少したゲノム領域を, SNP-index という指標を用いて同定する手法である。これは集 団遺伝学の研究において, selective sweepを検出する ことと同義である. QTL-seq 法を自然集団に適用する ことにより，自然選択の働いたゲノム領域を迅速に同定 することも期待される.

全ゲノム解析技術の発展により, 今後, 非モデル生物 の遺伝子同定が飛躍的に容易になるであろう. モデル生 物を中心に求心的に発展してきた生物学が, 一転して多 様性研究に向かうことが期待される. 将来の研究者に とって最も必要とされるのは, さまざまな自然環境に生 育している多様な生物を知り, その表現型と環境適応, 生物間の相互作用について観察する目である. ゲノム解 
析は,「自然に戻り (Back to the Nature)」, 生物理解 を進めることを可能にすると考えられる.

謝辞: 本研究は生研センターイノベーション創出事業の支援を受けて行 いました。ここに謝意を述べます。また，生研センター研究リーダーの 黒田秧氏には, 研究全般の指導について, 特に感謝を申し上げます.

1) J. N. Hirschhorn \& M. J. Daly : Nat. Rev. Genet., 6, 95 (2005).

2) K. Schneeberger, S. Ossowski, C. Lanz, T. Juul, A. H. Petersen, K. L. Nielsen, J.-E. Jorgensen, D. Weigel \& S. U. Andersen : Nat. Methods, 6, 550 (2009).

3) M. I. Ehrenreich, N. Torabi, Y. Jia, J. Kent, S. Martis, A. J. Shapiro, D. Gresham, A. A. Caudy \& L. Kruglyak : Nature, 446, 1039 (2010).

4) A. Abe, S. Kosugi, K. Yoshida et al. : Nat. Biotechnol., 30, 174 (2012)

5) H. Takagi, A. Abe, K. Yoshida et al. : Plant J., doi : 10.1111/tpj.12105 (2013).

(寺内良平, 阿部 陽, 高木宏樹, 小杉俊一, 吉田健 太郎, 夏目 俊, 八重樫弘樹, Muluneh Tamiru, 神崎洋之, 松村英生, 岩手生物工学研究センター)

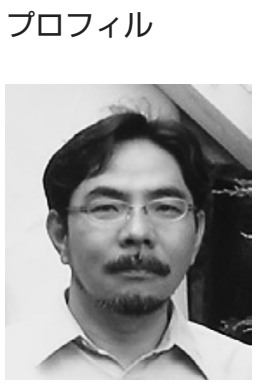

寺内 良平 (Ryohei TERAUCHI)

$<$ 略歴 $>1982$ 年京都大学農学部農林生物 学科卒業/ナイジェリア国際熱带農業研究 所ポスドク, 京都大学理学部助手, フラン クフルト大学ポスドク, 現職<研究テーマ と抱負>植物遺伝学

阿 部 陽 (Akira ABE)

$<$ 略歴 $>2001$ 年岩手大学大学院農学研究 科修士課程修了 / 2012 年同大学大学院連 合農学研究科博士課程修了 / $2002 \sim 2012$ 年岩手県農業研究センター／2012年岩手 生物工学研究センター, 現在に至る<研究 テーマと抱負>イネ重要形質の遺伝子同定 と育種利用

高木 宏樹 (Hiroki TAKAGI)

$<$ 略歴 $>2007$ 年新潟大学農学部農業生産 科学科卒業/同年同大学大学院自然科学研 究科 $/ 2011$ 年株式会社 HOB / 2012 年岩手 生物工学研究センター, 現在に至る $<$ 研究 テーマと抱負>次世代シーケンサーを用い た新規遺伝子単離技術の開発.これまでに 開発してきた遺伝子単離技術を用いて育種 上重要な遺伝子を単離すること＜趣味 $>$ 山 野草探索

\section{今日の話題}

小杉 俊一 (Shunichi KOSUGI)

<略歴>1986年筑波大学第二学群生物学 類卒業／同大学院博士課程修了／農業生物 資源研究所, 慶應義塾大学, 岩手生物工学 センターなどを経て, 現在かずさ DNA 研 究所プロジェクト研究員 $<$ 研究テーマと抱 負＞次世代シークエンシングデータの情報 解析（ゲノムアセンブリング，ゲノムアノ テーションなど）拉よ゙゙バイオインフォマ ティクス解析ツールの作成

吉田健太郎 (Kentaro YOSHIDA)

$<$ 略歴 $>2001$ 年京都大学農学部生物生産 科学科卒業/同年同大学大学院農学研究 科 / 2006 年博士農学の学位取得 / 2007 年 日本学術振興会特別研究員 $/ 2010$ 年岩手 生物工学研究センター研究員 $/ 2012$ 年日 本学術振興会海外特別研究員, 現在に至る <研究テーマと抱負 $>$ 植物病原菌の進化 く趣味>ハイキング

夏目 俊 (Satoshi NATSUME)

$<$ 略歴 $>1992$ 年岩手大学人文社会科学部 人文社会科学科卒業/IT業界に就職し, 宮城県で起業，岩手県で企業活動を行う。 現在は岩手生物工学研究センターにてバイ オインフォマティシャンとして活動の傍 ら, 博士課程で研究を行っている<研究 テーマと抱負>非モデル生物のデノボ・ア センブリ＜趣味＞コントラクト・ブリッジ

八重樫弘樹 (Hiroki YAEGASHI)

<略歴>1990年東北大学工学部電子工学 科卒業 / 1990 年ソニー株式会社 / 2011 年 岩手生物工学研究センター, 現在に至る <研究テーマと抱負 > 次世代シーケンサを 用いた全ゲノムシーケンス解析技術の開発 く趣味〉スポーツ観戦

\section{Muluneh Tamiru}

$<$ 略歴 $>2006$ 年 Georg-August-University, Goettingen大学農業学部博士号取得

神崎 洋之 (Hiroyuki KANZAKI) <略歴>1993年東北大学農学部農学研究 科博士課程修了/岩手生物工学研究セン ター主任研究員（現在は専門研究員）<研 究テーマと抱負 > 植物と病原菌の相互作 用, 植物のストレス応答 $<$ 趣味 $>$ 滝巡り, 読書, スポーツ観戦

松村 英生 (Hideo MATSUMURA)

<略歴>1991年東京大学農学部農業生物 学科卒業/同大学大学院, 同大学分子細 胞生物学研究所, 岩手生物工学研究セン 夕ー, 信州大学ヒト環境科学研究支援セン ター准教授 (現職) <研究テーマと抱負 > シークエンサーを活用したゲノム機能解析 技術, 高等植物の性決定機構 $<$ 趣味 $>$ 家族 との LINE 